\title{
三宅成智 学位論文審査要旨
}

$\begin{array}{ccccc}\text { 主査 } & \text { 海 } & \text { 藤 } & \text { 俊 } & \text { 行 } \\ \text { 副主查 } & \text { 北 } & \text { 野 } & \text { 博 } \\ \text { 同 } & \text { 中 } \\ \text { 村 } & \text { 廣 } & \text { 繁 }\end{array}$

\section{主論文}

Fetal anatomy of the lower cervical and upper thoracic fasciae with special reference to the prevertebral fascial structures including the suprapleural membrane （特に胸膜上膜を含む椎前筋膜構造に関連した、頸部下位・胸部上位の筋膜に関する胎児 の解剖)

（著者：三宅成智、竹内裕美、趙白皖（Cho Baik Hwan）、村上弦、藤宮峯子、北野博也） 平成23年 Clinical Anatomy 24巻 607頁～618頁 


\section{学 位 論 文 要 旨}

Fetal anatomy of the lower cervical and upper thoracic fasciae with special reference to the prevertebral fascial structures including the suprapleural membrane （特に胸膜上膜を含む椎前筋膜構造に関連した、頸部下位・胸部上位の筋膜に関する胎児 の解剖）

近年、心血管インターベンション治療や内視鏡手術のために、頸部や縦隔の筋膜に関し て詳細な知見が求められている。この領域の知見は、1930年代における妊娠後期の胎児標 本を用いた先駆的な研究に基づいているが、以降では頸部筋膜の組織学的な研究はあまり 進んでいない。本研究の目的は、下位頸部筋膜と上縦隔筋膜との基本的な形態を描出し、 深頸筋膜と縦隔筋膜の接続を支配する基本的な法則を調べることにある。

\section{方 法}

ホルマリン固定した妊娠中期の胎児標本 18 体を対象とした。内訳は、妊娠 $5-9$ 週の胎児 標本が5体、妊娠15-18週が3体、妊娠20-25週が10体である。パラフィン包埋した標本は、 18週以下の胎児では概ね $5 \mu \mathrm{m} 、 20$ 週以後では10 $\mu \mathrm{m}$ の厚さで切片を作製し、各々50 $\mu \mathrm{m}$ または100 $\mu \mathrm{m}$ 毎に観察を行った。切削方向は14体を水平断、4体を矢状断とした。全例に ついてHE染色を行ったが、早期胎児の一部の切片は平滑筋を同定して血管とリンパ管を区 別するために、 $\alpha$ 平滑筋アクチンの免疫染色を追加した。

\section{結 果}

椎前筋膜構造のうち、深頸筋膜椎前葉は頸長筋両腹の中間腱膜として発達していたが、 対照的に、翼状筋膜は両側の総頸動脈外膜の間を接続する帯として発達していた。咽後の 筋膜が明確になるのは、この二つの筋膜が形成されるよりも後の時期であつた。発達が進 むと翼状筋膜は（1）縦隔の大血管の血管鞘（2）気管や食道の後面 (3) 両側の臓側胸膜（胸 膜上膜）と結合していた。胸腺を覆う筋膜は前頸筋の筋膜（頸筋膜の気管前薄膜）よりも 肥厚していた。

発達早期の胸膜上膜は、静脈や脂肪組織を含んでおり、膜の構成主体は深頸筋膜椎前葉 や胸内筋膜ではなく、翼状筋膜であった。この部位の静脈は、外側椎骨静脈叢と交通して いた。椎前筋膜は発達の早い段階では、深頸筋膜椎前葉と翼状筋膜から成る2枚の薄膜構造 が明瞭であったが、後の段階になると椎前筋膜は複数の薄膜で構成されていた。この複数 
の薄膜は、特に頸長筋前方の外側部に顕著で、両側の胸膜頂を吊すように連結していた。

\section{考 察}

今回の研究で最も重要な発見は、発達の早い段階において、深頸筋膜椎前葉は頸長筋両 腹の中間腱膜として形成されるが、翼状筋膜は両側の総頸動脈外膜の間を接続する帯とし て形成されることである。翼状筋膜は発達すると大血管の血管鞘、気管や食道の後面、胸 膜上膜と結合することから、翼状筋膜こそが頸部と縦隔の筋膜系を結ぶ鍵となる構造だと 考えられた。

本研究の組織学的検討により、すでに妊娠中期の胎児では、結合組織が胸膜頂を吊り下 げて固定していることが明らかになった。この結合組織は豊富な静脈と脂肪組織を含んで いた。これを発達初期の胸膜上膜と考え、20世紀初頭の文献で示されたシブソン筋膜に該 当すると推定した。肺尖と胸膜上膜の結合が破綻することが、しばしば血気胸の原因にな るといら従来の報告があるが、その理由として、この静脈に富む椎前構造が炎症で癒着を 形成し、ときに出血を引き起こすと推察された。

小児の胸部単純X線撮影では肺尖部の突出した像に遭遇することがある。従来の報告では、 胸膜上膜が胸膜に緊密に融合することがこの像の原因であり、胸膜上膜の由来は深頸筀膜 椎前葉と連続する肥厚した胸内筋膜であると説明されていた。しかし、今回の研究によっ て、胸膜上膜の形成には、深頸筋膜椎前葉ではなく翼状筋膜が主に寄与していることが明 らかになった。

胸膜上膜以外の呼称でも、胸郭の頂点を結ぶ帯状組織を「椎骨 - 肋閒勒帯」などと記述 する多くの報告があり、胸郭出口症候群の原因と考えられてきた。斜角筋も胸郭出口を狭 くするとしてよく知られた構造であり、一般的な変異である最小斜角筋が胸膜頂に向かっ て腱膜（すなわち胸膜上膜）を生じるという報告もある。しかし、斜角筋や周囲の筋肉か ら胸膜上膜が供給されているという所見は本研究では認められなかった。恐らく出生後に、 胸膜上膜が肺の炎症や筋肉からの機械的な圧迫によって隣接した構造と緊密な癒合を起こ して著しく変化すると推察された。

\section{結 論}

翼状筋膜は、血管鞘と壁側胸膜を連結することにより、頸部基部から上縦隔への筋膜の 連続性を維持している重要な構造であると考えられた。 